\title{
A STUDY ON FRICTION STIR WELDING OF AISi1MgMn ALUMINIUM ALLOY PLATES
}

\author{
Nikola Šibalić, Milan Vukčević, Mileta Janjić, Sreten Savićević
}

Original scientific paper Presented in this paper are an experimental investigation and numerical simulations of the Friction Stir Welding (FSW) process. The aim was to determine thermo-mechanical and kinematic parameters of the process of joining two AlSilMgMn aluminium alloy plates with the thickness of 7,8 mm. Experimental study was designed based on the 2-level multifactorial design of experiment (DoE), with centre points. Parameters varied in the experiment were: welding speed, rotation speed, angle of pin slope, pin diameter and shoulder diameter. Based on the adopted geometric parameters, the family of tools was designed and manufactured for the experiment. The experiment was performed in laboratory conditions, which were similar to production environment. Numerical simulation of the FSW process was carried out using DEFORM-3D software. Detailed analysis of the process as well as comparison between experimental and numerical results is presented.

Keywords: Friction Stir Welding - FSW; impact toughness; numerical simulation; pin; shoulder; tensile strength; welding forces

\section{Studija zavarivanja trenjem lima od aluminijske legure AISi1MgMn}

U radu su prezentirana eksperimentalna istraživanja i numeričke simulacije procesa zavarivanja trenjem (FSW). Cilj rada je određivanje termomehaničkih i kinematičkih parametara procesa spajanja lima od aluminijske legure AlSilMgMn debljine 7,8 mm. Eksperimentalna istraživanja su projektirana na temelju usvojenog višefaktornog plana (DoE), s variranjem faktora na dvije razine i ponavljanjem u središnjoj točki plana. Parametri varirani u eksperimentu su: brzina zavarivanja, kutna brzina okretanja alata, kut nagiba trna, promjer trna i promjer čela alata. Na temelju usvojenih geometrijskih parametara projektirana je i izrađena familija alata. Eksperiment je proveden u laboratorijskim uvjetima, koji su slični proizvodnom okruženju. Za numeričku simulaciju procesa FSW, korišten je programski paket DEFORM-3D. U radu je prikazana detaljna analiza i usporedba istraživanih parametara dobivenih eksperimentalnim putem i numeričkom simulacijom.

Ključne riječi: čelo alata; lomna žilavost; numerička simulacija; sile zavarivanja; trn; zatezna čvrstoća; zavarivanje trenjem - FSW

\section{Introduction}

During the nineties of the last century a new method of joining similar and dissimilar materials in the solid state without melting of material, known as Friction Stir Welding - FSW was developed. The process was patented by The Welding Institute - TWI in England in 1991, and invented by Wayne M. Thomas who successfully joined plates of aluminium alloys $[1 \div 5,9,10]$. The method is primarily used to join plates of larger thickness. Tools that are used in the process of welding are cylindrical and consist of two concentric parts, which are rotating at high speed. The larger diameter part of the tool is called the shoulder, while the smaller diameter part is called the pin (Fig. 1). Rotating tool slowly approaches the joint line and plunges into material, generating heat. Due to that, the temperature increases to the heat metal forming where mechanical mixing and joining of materials is performed, enabling the tool to move in the longitudinal direction or along the joint lines (Fig. 2). After passing of the tool along the joint lines the solid phase of weld (joint) remains, where the upper plane remains smooth and flat thanks to the tool shoulder, while the lower plane of the workpiece is formed from the basis on which the workpiece is standing and is also smooth and flat $[1 \div 4]$.

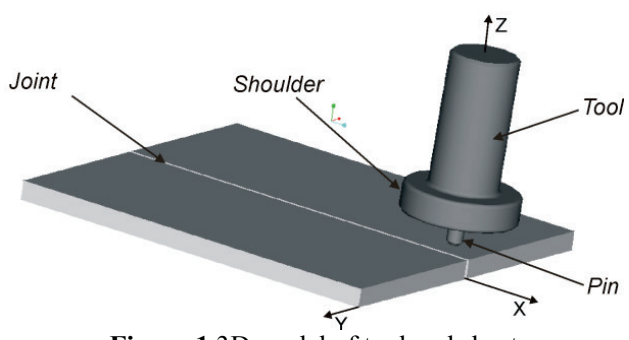

Figure 13D model of tool and sheet

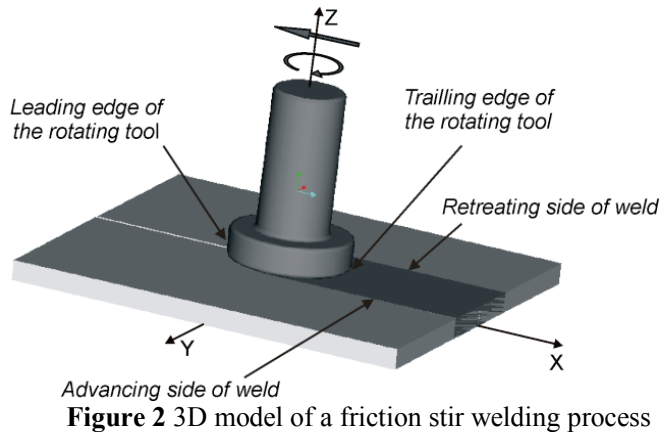

\section{Materials and experimental procedure}

For the friction stir welding process the vertical milling machine "Gorki" 6P13 was used. The material employed in the experiment was aluminium alloy sheet AlSi1MgMn, numerical label 6082-T6, whose chemical composition is given in Tab. 1 , and the mechanical properties of the basic material in Tab. 2. The dimension of the workpiece was $200 \times 50 \times 7,8 \mathrm{~mm}(L \times W \times H)$.

Table 1 The chemical composition of the used alloy AlSi1MgMn

\begin{tabular}{|c|c|c|c|c|c|c|c|c|c|c|}
\hline$\%$ & $\%$ & $\%$ & $\%$ & $\%$ & $\%$ & $\%$ & $\%$ & $\%$ & $\%$ & $\%$ \\
$\mathrm{Al}$ & $\mathrm{Fe}$ & $\mathrm{Si}$ & $\mathrm{Ti}$ & $\mathrm{Cu}$ & $\mathrm{Zn}$ & $\mathrm{V}$ & $\mathrm{Cr}$ & $\mathrm{Mn}$ & $\mathrm{Mg}$ & $\mathrm{Na}$ \\
\hline 98,25 & 0,21 & 0,83 & 0,01 & 0,002 & 0,060 & 0,006 & 0,001 & 0,15 & 0,43 & 0,001 \\
\hline
\end{tabular}

Table 2 Mechanical properties of the used alloy AlSi1MgMn

\begin{tabular}{|c|c|c|c|c|}
\hline $\begin{array}{c}\text { Proof stress } \\
0,2 \% \\
\mathrm{MPa}\end{array}$ & $\begin{array}{c}\text { Tensile } \\
\text { strength } \\
\mathrm{MPa}\end{array}$ & $\begin{array}{c}\text { Shear } \\
\text { strength } \\
\mathrm{MPa}\end{array}$ & $\begin{array}{c}\text { Elongation A5 } \\
\%\end{array}$ & $\begin{array}{c}\text { Melting } \\
\text { point } \\
{ }^{\circ} \mathrm{C}\end{array}$ \\
\hline 310 & 340 & 210 & 11 & 555 \\
\hline
\end{tabular}

Material of welding tool was 1.2343 steel according to the standard EN 10027-2. The tool was designed in 
Pro/Engineer, using a program for parametric modelling (Fig. 3a).

\subsection{Definition of experiment}

The aim of experimental investigation was to determine the influence of the tool geometric parameters on thermo-mechanical and kinematic characteristics of the stir welding process. For that purpose a family of tools with different geometrical parameters was developed. The axisymmetrical tool consists of the working part and tool body. The body of the tool is adjusted to the jaws of machine that is used in the experiment. Tool geometry is presented in Fig. 3b.

a)

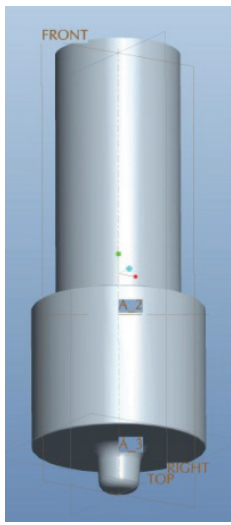

b)

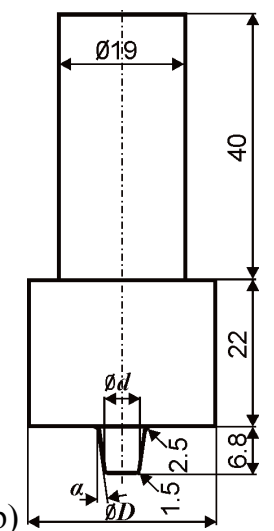

Figure 3 The tool with adopted dimensions and parameters $D, d$ and $\alpha$

\subsection{Design of experiment (DoE)}

Based upon preliminary investigation, the 2-level factorial orthogonal plan with four enter points $\left(n_{0}=4\right)$ was adopted. As the input values, the elements of welding regime and geometric factors of the tool were chosen: $X_{1}=v \mathrm{~mm} / \mathrm{min}$ (welding speed), $X_{2}=\omega \mathrm{rpm}$ (rotation speed of tool), $X_{3}=\alpha$ (angle of pin slope), $X_{4}=d \mathrm{~mm}$ (pin diameter) and $X_{5}=D \mathrm{~mm}$ (diameter of the shoulder). The adopted levels of variation of input factors are given in Tab. $3[5]$.

Table 3 Levels of input factors

\begin{tabular}{|c|c|c|c|}
\hline Input factors & Upper level & Lower level & Basic level \\
\hline$X_{1}$ & 200 & 80 & 125 \\
\hline$X_{2}$ & 1000 & 630 & 800 \\
\hline$X_{3}$ & 5 & 3 & 3,87 \\
\hline$X_{4}$ & 7 & 5 & 5,92 \\
\hline$X_{5}$ & 28 & 25 & 26,46 \\
\hline
\end{tabular}

Based on adopted values $X_{3}, X_{4}$ and $X_{5}$ the set of nine tools was designed and manufactured, Fig. 4.

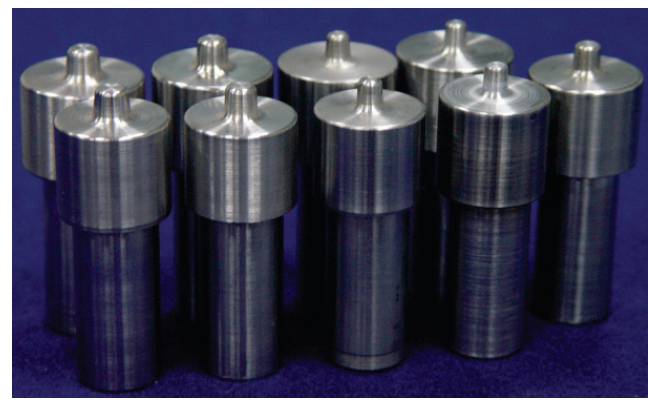

Figure 4 Set of tools designed according to DoE [5]

\subsection{The performance of experiment}

Experimental investigation was performed in two phases.

Phase I: measurement of welding forces (downward force - $F z$, longitudinal force - $F x$ and side force $-F y$ ) and workpiece temperature at six locations.

Phase II: mechanical testing of the welded joint.

Research site is presented in Fig. 5 and Fig. 6 provides an overview of welded workpieces for $36^{\text {th }}$ point of experimental plan.

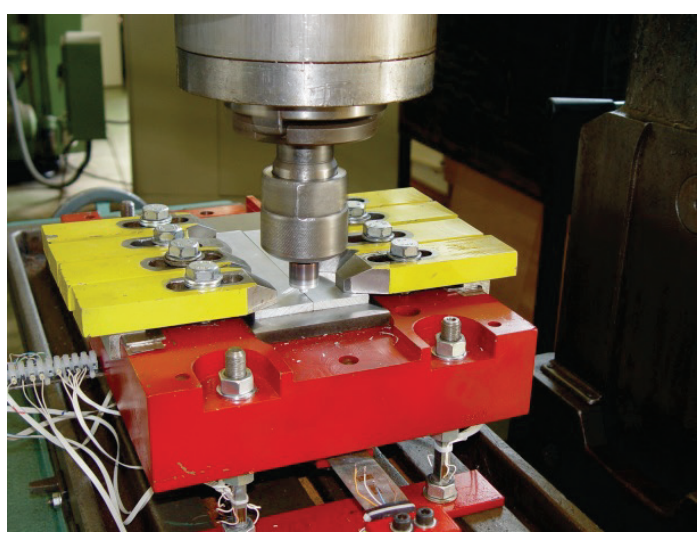

Figure 5 Experimental platform

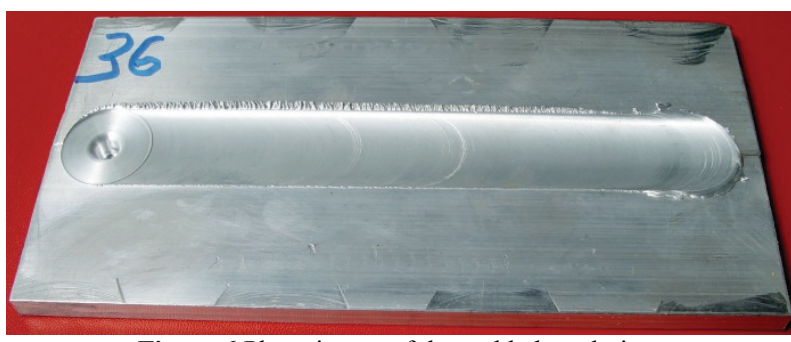

Figure 6 Photo image of the welded workpiece

During the FSW process, forces were measured using precise analog-digital equipment connected to the information measurement system. The sensors, measuring tapes (HBN 6/120LY11), were cemented on special holders which were adjusted to experiment requirements.

Fig. 7 shows force-time diagram at the centre point of DoE. When the rotating tool plunges into the material (workpiece), force $F z$ equals $6,61 \mathrm{kN}$. The workpiece is heated because of the friction between the pin and the workpiece. After the plunge, force $F z$ begins to decline until the shoulder contacts the workpiece surface. At this moment the force reaches its maximum value $(8,25 \mathrm{kN})$, because a large area of the shoulder begins to plunge into the workpiece. Due to the friction between the shoulder and the pin with the material, intensive heating of the workpiece takes place.

During execution of the welding process the force $F z$ begins to decline until the moment when the milling machine is programmed to start longitudinal movement of the table. After that, force $F z$ retains its constant value, until the tool exits the workpiece.

The values of $F x$ force depend mainly on the welding speed but tool geometry also influences this force to some extent. During the welding process, force $F y$ has lowest values. 


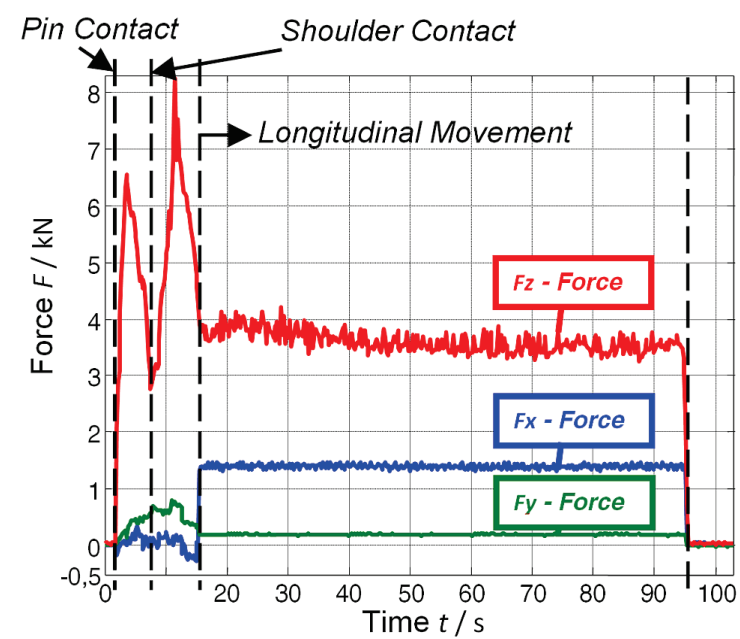

Figure 7 Diagram of forces $F z, F x$ and $F y$ in the FSW process

In order to conduct temperature measurements, thermo-couples of Al-Cr wire were placed into the workpiece at the locations given in Fig 8.

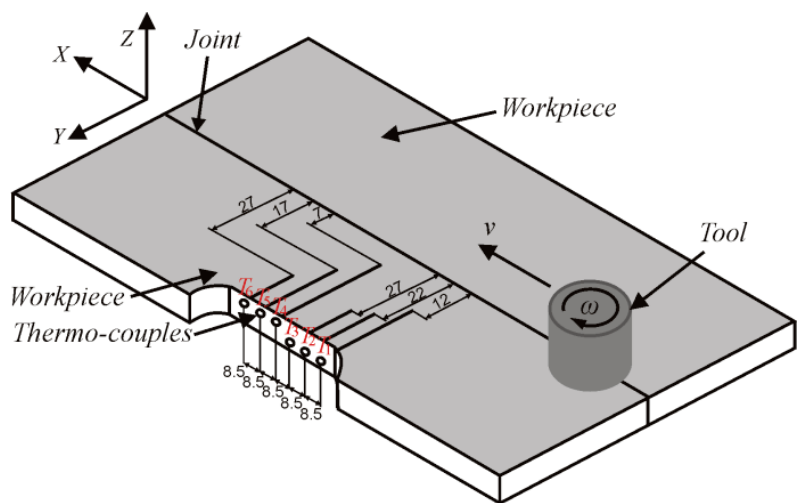

Figure 8 Location of thermo-couples within the workpiece

Location thermo-couples, shown in Fig. 8, allow the measurement of temperature in micro structural zones. In this way we obtain a complete picture of the generation and distribution of heat through the material. Fig. 9 shows the measured values of temperature in the $2^{\text {nd }}\left(v_{2}=80\right.$ $\mathrm{mm} / \mathrm{min} ; \omega_{2}=1000 \mathrm{rpm} ; \alpha_{2}=5^{\circ} ; d_{2}=7 \mathrm{~mm} ; D_{2}=28$ $\mathrm{mm}$ ) point of DoE.

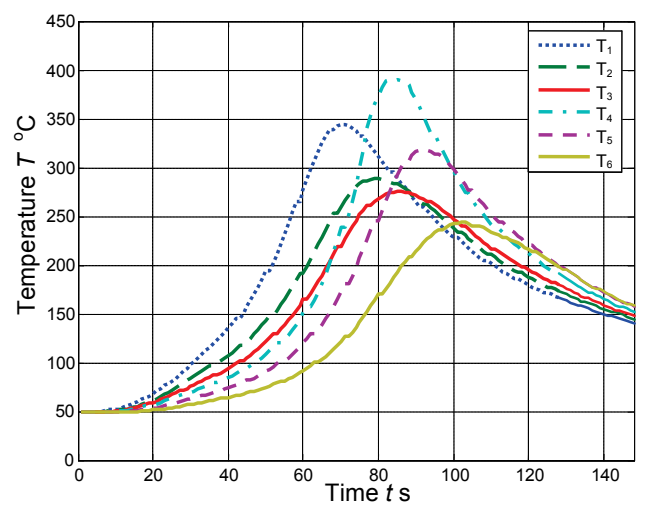

Figure 9 The temperature diagram at the $2^{\text {nd }}$ point of DoE

\section{Mechanical testing}

During the FSW process, in the stirred zone significant micro structural evolution takes place, which leads to the substantial changes of mechanical properties within and around the welded joint.

Tensile and toughness properties of the welded workpiece were also investigated. Specimens for tensile test were machined in two different directions relative to the weld: longitudinal and transverse. The arrangement of specimens in welded workpieces was made according to standard for testing of welded joints.

For the Charpy impact test one specimen was machined from the "nugget" zone in lateral direction, where the V-notches were positioned at the opposite sides of the welding direction. Fig. 10 shows position of the specimens for the tensile and impact tests within the welded workpiece.

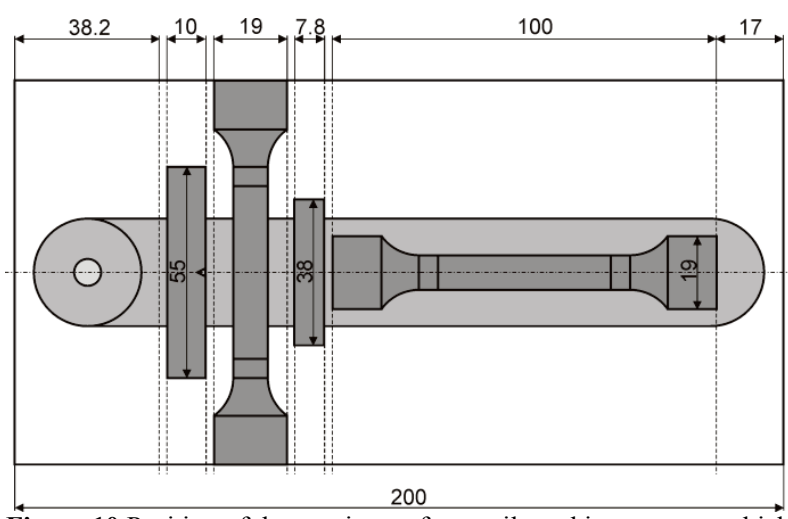

Figure 10 Position of the specimens for tensile and impact tests which were cut out from the welded workpiece

\subsection{Determination of tensile strength}

Tensile test was carried out on the $200 \mathrm{kN}$ tensile machine. Flat specimens, according to standard EN 10002-1:2008 [6] were used. Testing was conducted at room temperature. For the purpose of tensile testing, 72 specimens were cut from welded workpieces to provide data for all DoE points, while 4 specimens were made from the basic material, which was not welded. Fig. 11 shows the specimen, and Fig. 12 and Fig. 13 present photo images of specimen at the centre points of DoE, in $\mathrm{x}$ and $\mathrm{y}$ directions.

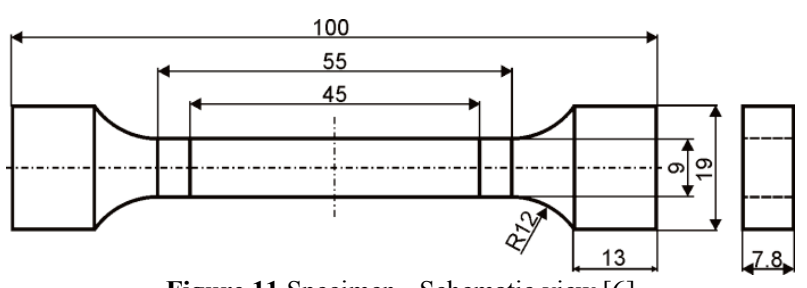

Figure 11 Specimen - Schematic view [6]

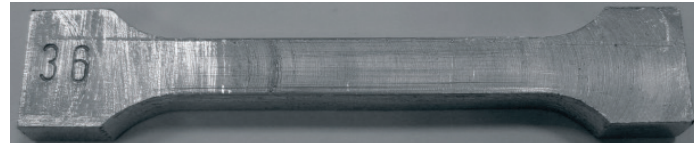

Figure 12 Specimen for tensile testing, $y$-direction normal to the welding direction

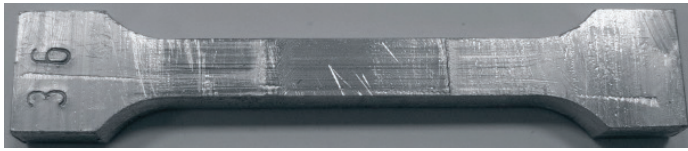

Figure 13 Specimen for tensile testing, $x$ - direction that coincides with the welding direction 
Using a predetermined welding parameters (rotation speed of tools: $1000,800,630 \mathrm{rpm}$, and welding speed: 200, 125 and $80 \mathrm{~mm} / \mathrm{min}$ ), different values of tensile strength $R m$ were obtained. Fig. 14 shows the diagram of tension for the specimen at the centre points of DoE, from $x$ and $y$-direction, with the values of tensile strength $R m$.

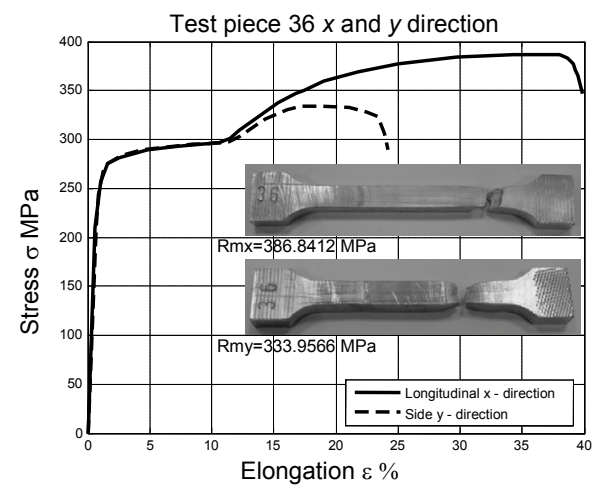

Figure 14 Diagram: Stress - Elongation

The diagram shows that the tensile strength is higher for the specimens taken from the longitudinal $(x)$ direction than for the specimens taken from the lateral $(y)$ direction. The ratio between tensile strengths $R m_{x} / R m_{y}$ is 1,158 , while the elongation $\varepsilon_{x} / \varepsilon_{y}$ ratio of the specimen from $x$ and $y$ - direction is 1,66 .

\subsection{Determination of impact toughness}

Charpy impact tests of welded material were performed with a maximum available initial energy of $150 \mathrm{~J}$.

When the impact occurs, the specimen is exposed to bending. Toughness of the welded material or impact strength to bending, equals the work applied to break the specimen, reduced to a unit of the specimen cross-section:

$\rho=\frac{N}{A}, \mathrm{~J} / \mathrm{cm}^{2}$

The specimens were made according to the standards EN 10045-1:1993 [7], (Fig. 15). A narrow specimen with a V-notch was adopted.

The value of impact toughness of the basic material is $\rho=70 \mathrm{~J} / \mathrm{cm}^{2}$. Test results showed that the lowest impact toughness values of FSW workpieces appeared in the $17^{\text {th }}$ $\left(v_{17}=200 \mathrm{~mm} / \mathrm{min} ; \omega_{17}=1000 \mathrm{rpm} ; \alpha_{17}=5^{\circ} ; d_{17}=7\right.$ $\left.\mathrm{mm} ; D_{17}=25 \mathrm{~mm}\right)$ and $18^{\text {th }}\left(v_{18}=80 \mathrm{~mm} / \mathrm{min} ; \omega_{18}=\right.$ $\left.1000 \mathrm{rpm} ; \alpha_{18}=5^{\circ} ; d_{18}=7 \mathrm{~mm} ; D_{18}=25 \mathrm{~mm}\right)$ DoE points $\left(\rho_{17}=13.33 \mathrm{~J} / \mathrm{cm}^{2}\right.$ and $\left.\rho_{18}=10 \mathrm{~J} / \mathrm{cm}^{2}\right)$.
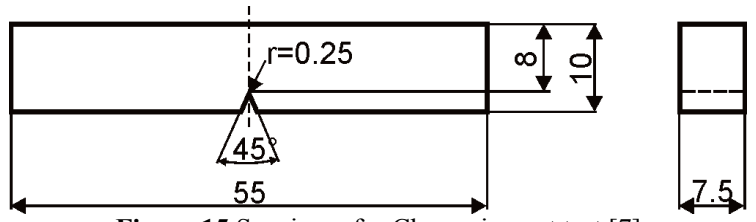

Figure 15 Specimen for Charpy impact test [7]

The highest value of impact toughness was obtained for the centre point $35\left(v_{35}=125 \mathrm{~mm} / \mathrm{min} ; \omega_{35}=800 \mathrm{rpm}\right.$; $\left.\alpha_{35}=3,87^{\circ} ; d_{35}=5,92 \mathrm{~mm} ; D_{35}=26,46 \mathrm{~mm}\right)$ and it is $\rho_{35}=66,66 \mathrm{~J} / \mathrm{cm}^{2}$.

\section{Numerical simulation}

DEFORM-3D was used for finite element analysis [8, 9]. Workpieces were designed in Pro/ENGINEER. In order to be able to compare the results obtained by numerical simulation and experiment, 36 simulations of FSW were performed, which correspond to DoE points. Numerical simulation consisted of two stages. The first stage simulated the tool plunging into the material to the depth of $6,9 \mathrm{~mm}$. In fact, the shoulder also plunges 0,1 $\mathrm{mm}$ into the workpiece. In the second stage, the process of welding was simulated, with the longitudinal tool travel of $166 \mathrm{~mm}$.

After entering input data and generating finite element mesh, boundary conditions were entered in order to carry out simulation of the FSW process. Simulation results were interpreted in the Post Processor module, in graphical and numerical form. Fig. 16 shows the 3D model used in the first stage of numerical simulations with generated mesh of finite elements and tool.

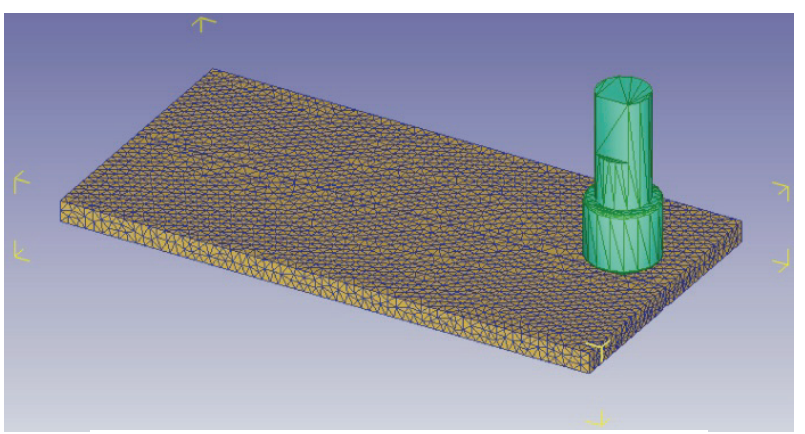

Figure 16 Workpiece and tool with the generated mesh

Simulation of the first stage ended with the $117^{\text {th }}$ step. The downward welding force, $F z$, obtained in this stage, is given in Fig. 17.

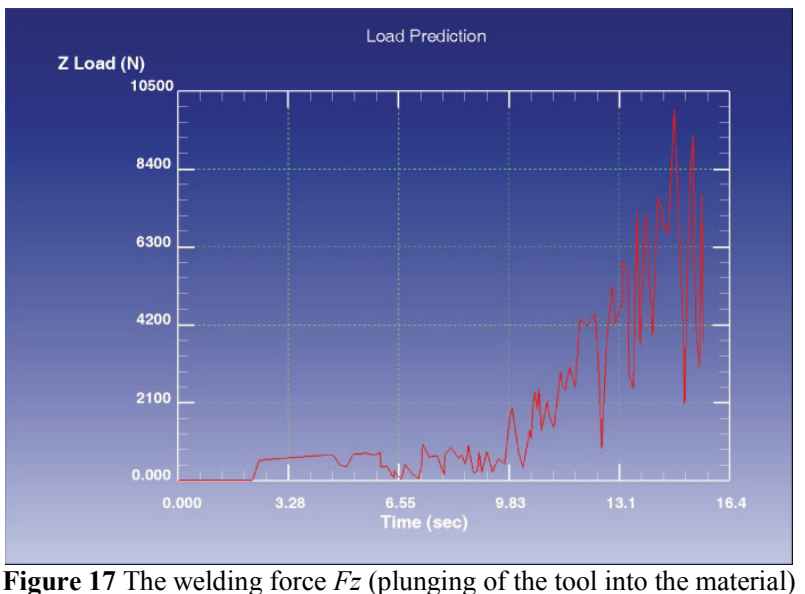

The final distribution of temperature fields in the workpiece (in the $117^{\text {th }}$ step) as the result of tool action, is given in Fig. 18.

The second stage of the simulation was completed in the $1805^{\text {th }}$ step. Fig. 19 shows the downward force $F z$ time diagram for the second stage of simulation. 


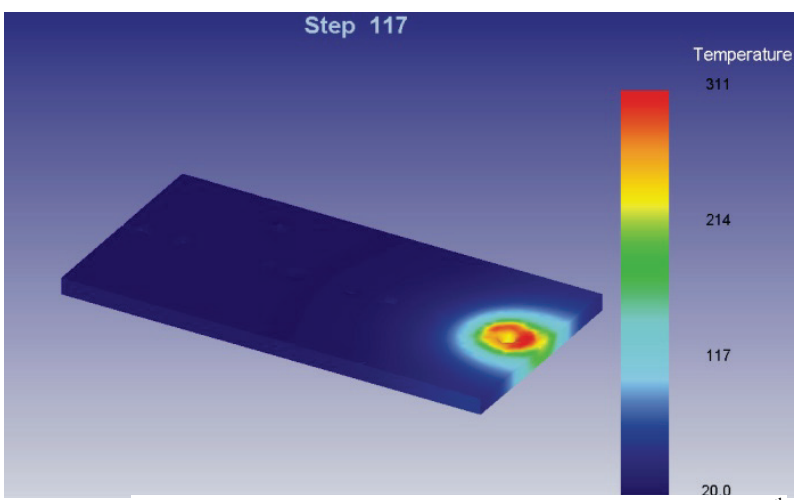

Figure 18 Distribution of temperature fields in workpiece in the $117^{\text {th }}$ step

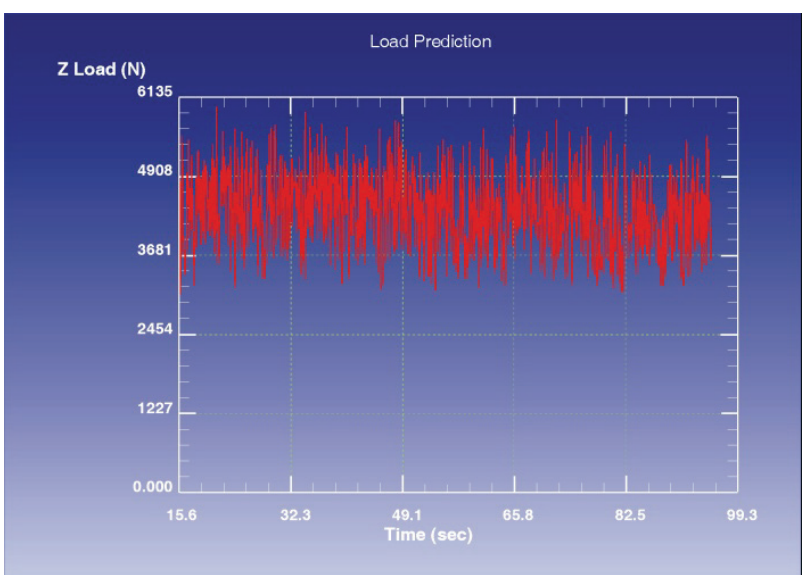

Figure 19 The welding force $F z$ (joining process)

Due to the large number of steps at this stage of simulations, only characteristic steps of the temperature distribution are presented (Fig. 20).
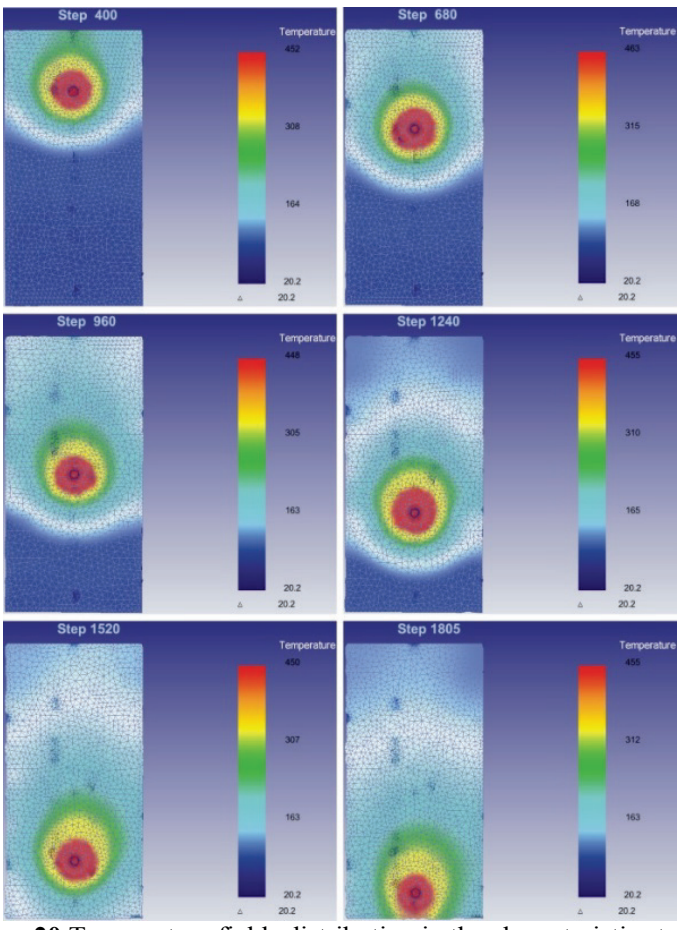

Figure 20 Temperature fields distribution in the characteristic steps of numerical simulation

For the predefined measurement points (Fig. 8), temperature values were obtained and shown in Fig. 21, for numerical simulation number 36 .

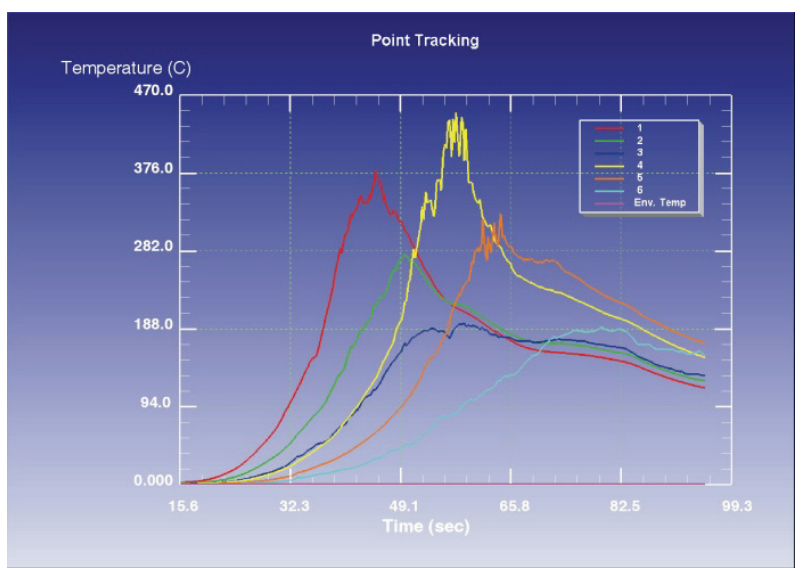

Figure 21 The resulting temperature diagram for the $36^{\text {th }}$ numerical simulation at the six selected nodal points

\section{$5 \quad$ Results and Discussion}

In this experimental investigation the following results were obtained: diagrams of forces that occur during the welding process, temperature charts, diagrams or elongation (values of tensile strength) and impact toughness values.

Visual analysis of FSW joint component revealed flaws and defects that are visible to plain eye at the top and bottom surface of the weld, as shown in Fig. 22, where the upper surface of the weld is shown for the $36^{\text {th }}$ $\left(v_{36}=125 \mathrm{~mm} / \mathrm{min} ; \omega_{36}=800 \mathrm{rpm} ; \alpha_{36}=3,87^{\circ} ; d_{36}=5.92\right.$ $\left.\mathrm{mm} ; D_{36}=26,46 \mathrm{~mm}\right)$ DoE point.

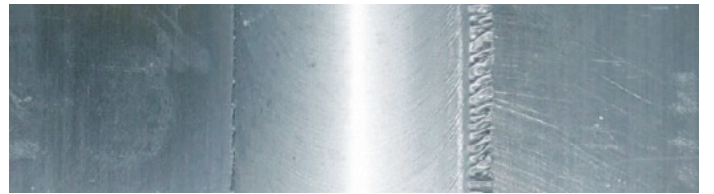

Figure 22 A visual overview of FSW weld, at the upper surface of welded workpieces

Fig. 23 shows the visual view of the lower surface of the weld for the $36^{\text {th }}$ DoE point, with clearly separated zones created under the influence of pin and shoulder.

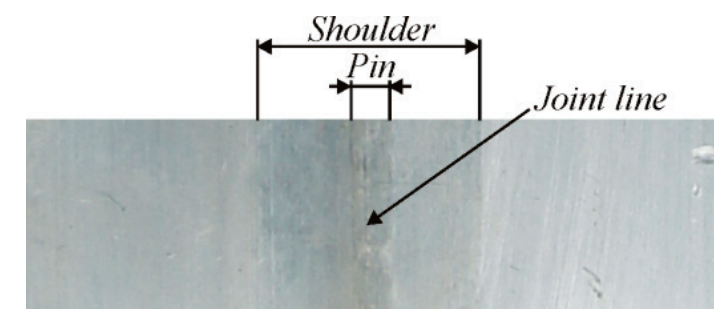

Figure 23 A visual overview of FSW weld, at the lower surface of welded workpieces

Fig. 24 and 25 show the diagrams of forces $F z, F x$ and $F y$ obtained experimentally and by numerical simulation, for the DoE points $3\left(v_{3}=200 \mathrm{~mm} / \mathrm{min}\right.$; $\left.\omega_{3}=630 \mathrm{rpm} ; \alpha_{3}=5^{\circ} ; d_{3}=7 \mathrm{~mm} ; D_{3}=28 \mathrm{~mm}\right), 28$ $\left(v_{28}=80 \mathrm{~mm} / \mathrm{min} ; \omega_{28}=630 \mathrm{rpm} ; \alpha_{28}=5^{\circ} ; d_{28}=5 \mathrm{~mm}\right.$; $\left.D_{28}=25 \mathrm{~mm}\right)$ and $33\left(v_{33}=125 \mathrm{~mm} / \mathrm{min} ; \omega_{33}=800 \mathrm{rpm}\right.$; $\left.\alpha_{33}=3,87^{\circ} ; d_{33}=5.92 \mathrm{~mm} ; D_{33}=26,46 \mathrm{~mm}\right)$.

Analysis of obtained results reveals that the downward force $F z$ is largely affected by the tool geometry, especially the size of the shoulder. All the 
obtained values of force $F z$ can be divided into three areas. The first 16 points of DoE belong to the first area (shoulder diameter of $28 \mathrm{~mm}$ ). The second area contains DoE points from 17 to 32, (shoulder diameter of $25 \mathrm{~mm}$ ), while the third area contains the centre DoE points.

In numerical simulations, the values of force $\mathrm{Fz}$ can also be divided into three areas, depending on the size of the shoulder.

Dependence of $F z$ on shoulder diameter, $D$, obtained by numerical analysis and experimentally is given in Fig. 26.
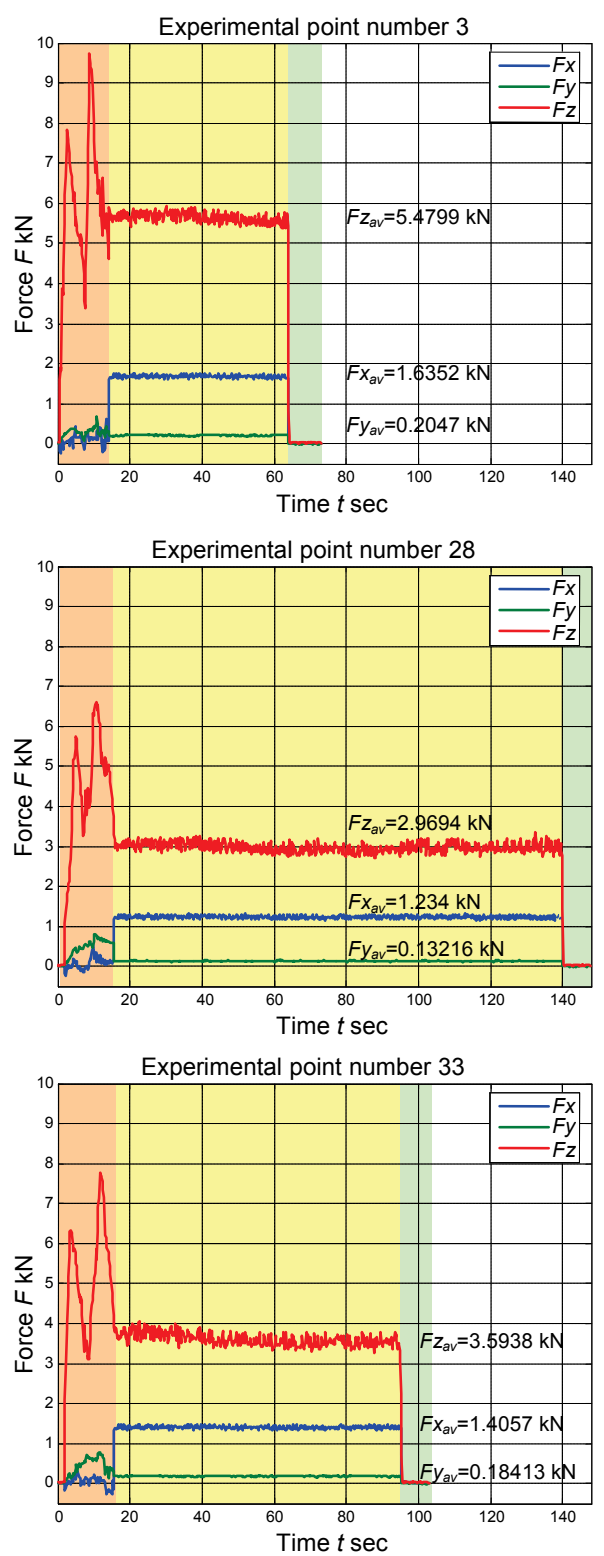

Figure 24 Diagrams of forces $F z, F x$ and $F y$ obtained by experiment

As can be seen from Fig. 24, 25 and 26, numerical results for the $F z$ are slightly higher than experimental. This can be attributed to the large physical nonlinearity of FSW process.

Temperature measurement was conducted at six points of the workpiece, positioned in two sections, $U$ and L, as shown in Fig. 27.

Temperature distribution is presented by contour diagrams for intersections $U$ and $L$ (Fig. 27) where the values of the measured temperature in ${ }^{\circ} \mathrm{C}$ are given.
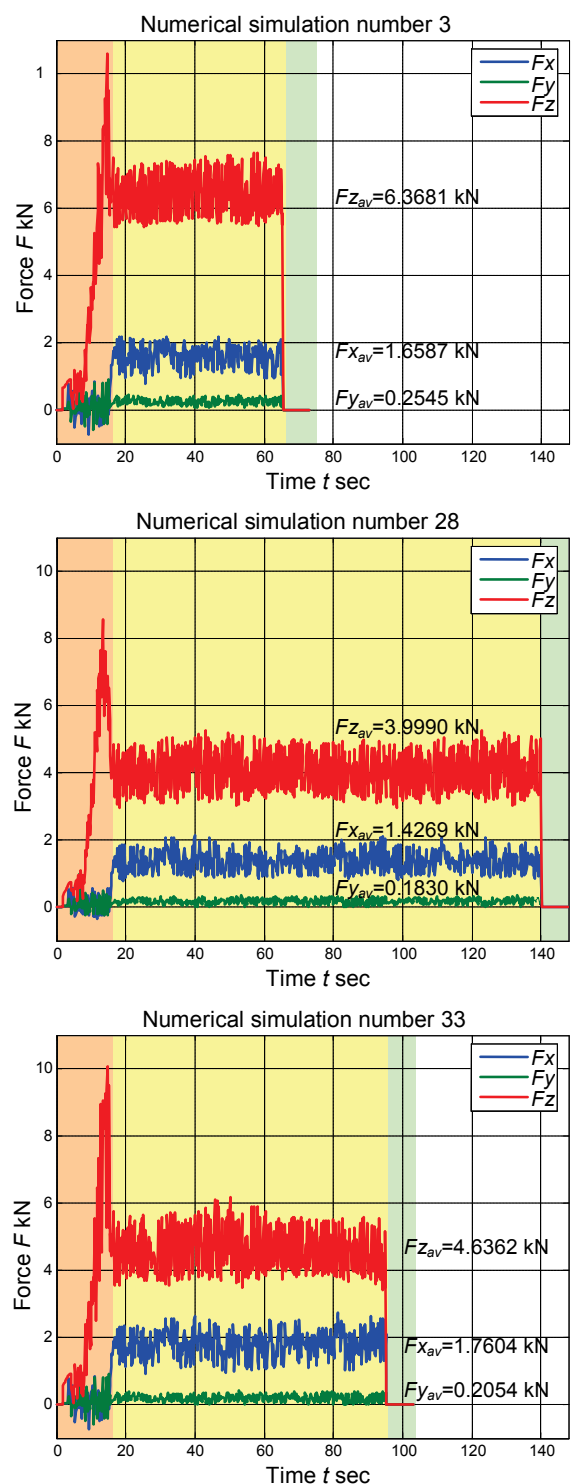

Figure 25 Diagrams of forces $F z, F x$ and $F y$ obtained by numerical simulation

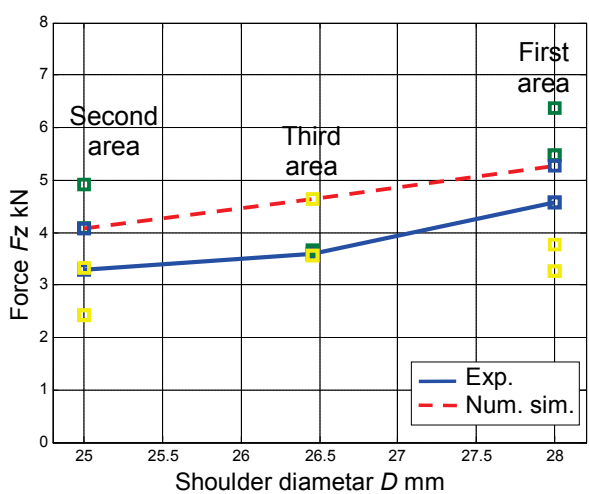

Figure 26 The values of downward force $F z$ as a function of shoulde diameter

Fig. 28 shows the contour diagram of the measured temperature in the first point of experimental plan at intersection $U$ for the tool position I, while Fig. 29 shows the temperature distribution at intersection $\mathrm{L}$ for the tool position II. 


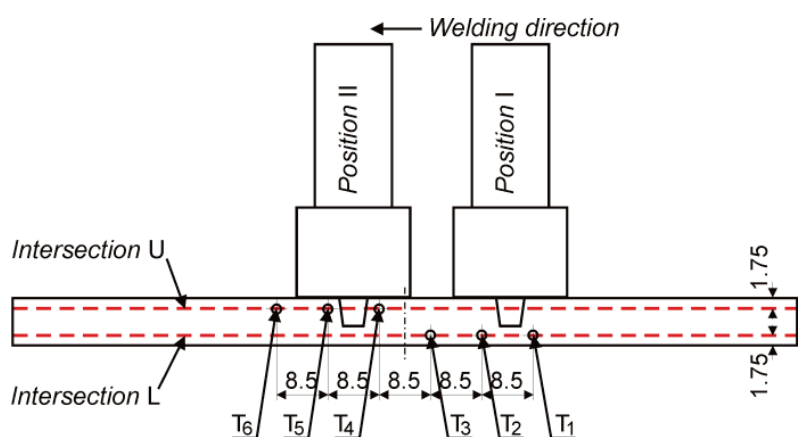

Figure 27 Layout of the thermo-couples inside the workpiece longitudinal view

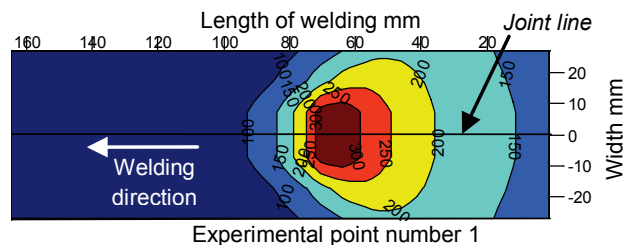

Figure 28 Contour diagram of the measured temperature for intersection $\mathrm{U}$ and tool position I

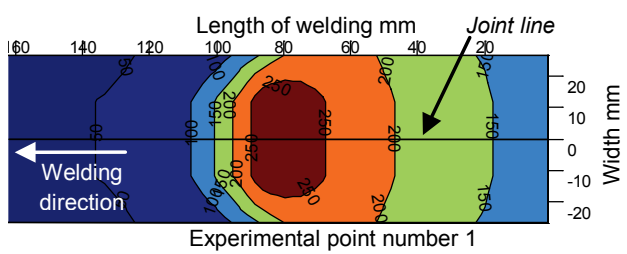

Figure 29 Contour diagram of the measured temperature for intersection $\mathrm{L}$ and tool position II

It can be seen from a schematic view (Fig. 30) that the selected cross-section, $\mathrm{ABCD}$, represents all the micro-structural zones within the workpiece.

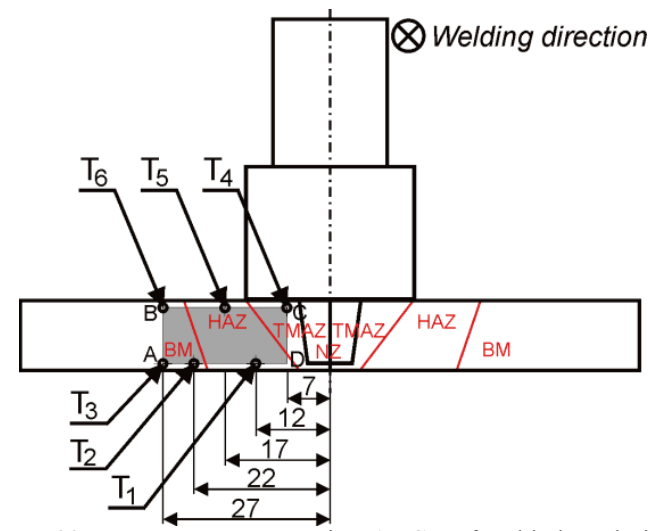

Figure 30 Transverse cross-section ABCD of welded workpieces

As the measurement position $\mathrm{T}_{4}$ is only a few millimetres away from the approaching pin (depending on the experimental points), it allows insight into temperature of the "nugget" zone. Measuring position $T_{1}$, yields temperatures in the transitional zone of thermomechanical effects, within the heat affected zone (HAZ), while measuring position $\mathrm{T}_{5}$ yields temperatures in the HAZ.

Temperature values of the HAZ crossing in the base material can be obtained in the measuring position $\mathrm{T}_{2}$, and measuring positions $T_{3}$ and $T_{6}$ give the temperatures of the base metal.

Fig. 31 shows contour diagrams of the observed cross-section $\mathrm{ABCD}$ for the DoE points $3\left(v_{3}=200\right.$ $\mathrm{mm} / \mathrm{min} ; \omega_{3}=630 \mathrm{rpm} ; \alpha_{3}=5^{\circ} ; d_{3}=7 \mathrm{~mm} ; D_{3}=28$ $\mathrm{mm}), 24\left(v_{24}=80 \mathrm{~mm} / \mathrm{min} ; \omega_{24}=630 \mathrm{rpm} ; \alpha_{24}=3^{0}\right.$; $\left.d_{24}=7 \mathrm{~mm} ; D_{24}=25 \mathrm{~mm}\right)$ and $36\left(v_{36}=125 \mathrm{~mm} / \mathrm{min} ; \omega_{36}\right.$ $\left.=800 \mathrm{rpm} ; \alpha_{36}=3,87^{\circ} ; d_{36}=5.92 \mathrm{~mm} ; D_{36}=26,46 \mathrm{~mm}\right)$, obtained by thermo-couples.
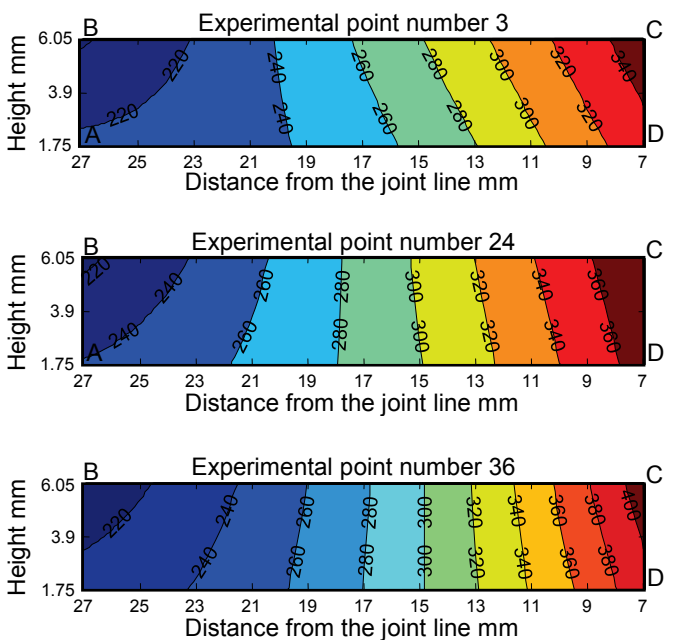

Figure 31 Contour diagrams of the measured temperatures in the crosssection $\mathrm{ABCD}$

Points $T_{1}$ to $T_{6}$ were considered for the analysis of numerically obtained temperature distribution. Temperature distribution for the simulation number 3 in the upper zone (intersection $U$ ) of the tool position (Fig. 27), is given in Fig. 32. The same diagram for the lower zone (intersection L) is given in Fig. 33.

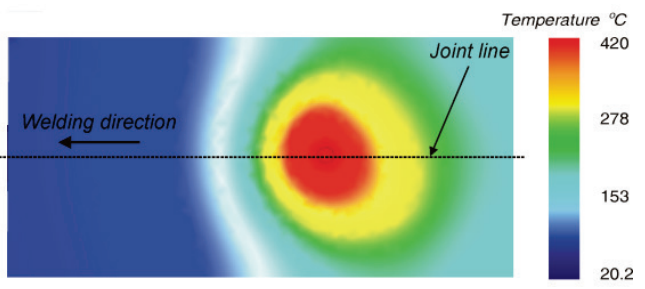

Figure 32 Shaded diagram of temperature in the upper zone U obtained by numerical simulation

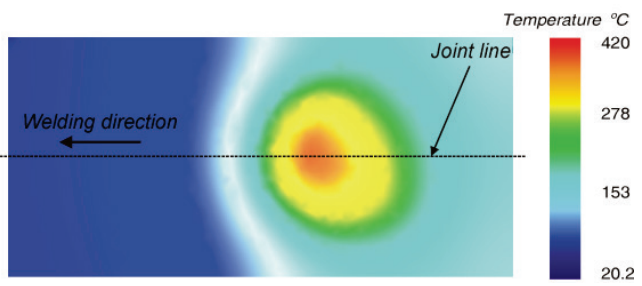

Figure 33 Shaded diagram of temperature in the lower zone L obtained by numerical simulation

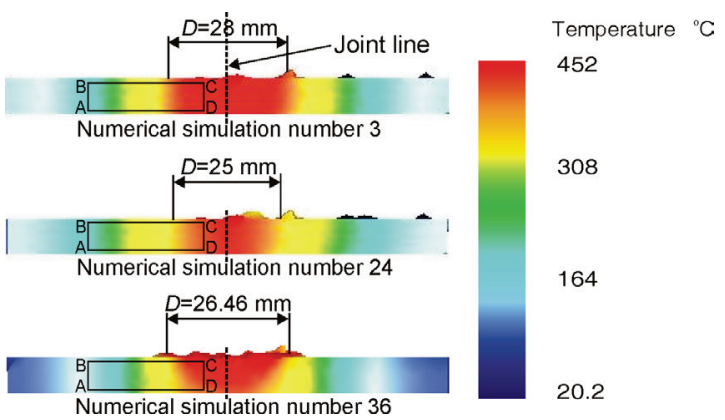

Figure 34 Shaded diagram of measured temperature in the transverse cross-section 
Fig. 34 shows shaded diagram of temperature, obtained in the characteristic cross-section ABCD for simulations number 3, 24 and 36 .

Temperature distributions for the upper (U) and lower (L) section of the workpiece, as the function of distance from the joint line, obtained by DEFORM simulation at the $36^{\text {th }}$ DoE point and experimentally, are given in Fig. 35 .

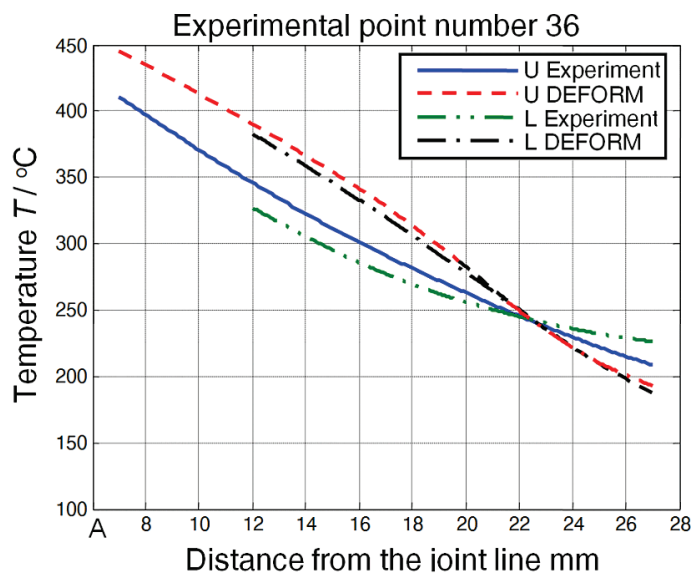

Figure 35 Temperature distribution in the upper (U) and lower (L) section of the workpiece for the $36^{\text {th }}$ DoE point

By comparing temperature distribution obtained numerically and experimentally, one concludes that DEFORM gives slightly higher temperatures than measurement. This difference is about $10 \%$ and it becomes smaller as the distance from the joint line increases.

\section{Conclusion}

An AlSi1MgMn Aluminium Alloy was joined by friction stir welding, applying various process parameters. The impact of different input welding parameters on welding forces in $x, y$ and $z$ direction, as well as the temperature fields distribution within the workpiece, was investigated numerically (FEM) and experimentally. Furthermore, mechanical properties (tensile strength and impact toughness of the joints) were determined and discussed.

For the purpose of this experiment, special tool and auxiliary equipment were developed.

The results thus obtained reveal that tool geometry (shoulder diameter, pin diameter and angle of pin slope) and regimes of welding (welding speed and rotation speed) exert major influence on the weld quality. This can be confirmed by the analysis of mechanical parameters (tensile strength and impact strength).

Welding forces obtained by numerical simulation are approximately $10 \%$ higher than experimental forces. This can be explained by imperfections of the experiment and numerical simulation, which requires further analysis.

Comparison of experimentally obtained temperature values measured at six locations of the workpiece with the values obtained by numerical simulation shows a relatively good agreement, with the difference below 10 $\%$. This allows the conclusion that heat generation and temperature distribution within the workpiece in FSW process can be successfully simulated by FEM.
Further investigation will be directed towards establishing a generalized model of FWS which would enable a complex analysis of this process, including impact of all relevant parameters as well as their interrelation.

\section{References}

[1] Dawes, C.; Thomas, W. Friction Stir Process Welds Aluminum Alloys. // Welding Journal. 75, 3(1996), pp. 41-45.

[2] Reynolds, A. Visualization of Material Flow in Autogenous Friction Stir Welds. // Science and Technology of Welding and Joining. 5, 2(2000), pp. 120-124. DOI: 10.1179/136217100101538119

[3] Vukčević, M.; Plančak, M.; Janjić, M.; Šibalić, N. Research and Analysis of Friction Stir Welding Parameters on Aluminium Alloys (6082-T6). // Journal for Technology of Plasticity. 34, 1-2(2009), pp. 49-57.

[4] Uyyuru, K. R.; Kailas, V. S. Numerical Analysis of Friction Stir Welding Process. // Journal of Materials Engineering and Performance. 15, 5(2006), pp. 505-518. DOI: $10.1361 / 105994906 \times 136070$

[5] Vukčević, M.; Janjić, M.; Plančak, M.; Šibalić, N. Optimization of Friction Stir Welding Parameters on Aluminium Alloys AlSi1MgMn. // Steel Research International - Special Edition 2010. 81, 9(2010), pp. 10801083.

[6] Standard. Metallic materials - Tensile testing - Part 1: Method of test at ambient temperature. // Institute for standardization of Montenegro. MEST EN 10002-1, 2008.

[7] Standard. Mechanical testing of metals - Charpy impact test - Part 1: Test method. // Institute for standardization of Montenegro. MEST EN 10045-1, 1993.

[8] Fluhrer, J. DEFORM 3D Version 6.1 User's Manual. Scientific Forming Technologies Corporation - SFTC, Ohio, 2007.

[9] Buffa, G.; Fratini, L.; Micari, F. Finite Element Simulation of Friction Stir Welding. // Steel Research International Special Edition 2010. 81, 9(2010), pp. 1070-1073.

[10] Chang, W. S.; Rajesh, R. S.; Chun, C. K.; Kim, H. J. Microstructure and Mechanical Properties of Hybrid LaserFriction Stir Welding Between AA6061-T6 Al Alloy and AZ31 Mg Alloy. // Journal of Materials Science \& Technology. 27, 3(2011), pp. 199-204. DOI: 10.1016/S10050302(11)60049-2

\section{Authors' addresses}

Nikola Šibalić, Assist. prof., Ing., Ph.D.

University of Montenegro, Faculty of Mechanical Engineering Džordža Vašingtona bb, 81000 Podgorica, Montenegro Tel: +382 20245003

E-mail: nikola.sibalic@ac.me

Milan Vukčević, Full prof., Ing., Ph.D.

University of Montenegro, Faculty of Mechanical Engineering Džordža Vašingtona bb, 81000 Podgorica, Montenegro E-mail: milan.vukcevic@ac.me

Mileta Janjić, Assoc. prof., Ing., Ph.D.

University of Montenegro, Faculty of Mechanical Engineering Džordža Vašingtona bb, 81000 Podgorica, Montenegro E-mail: mileta.janjic@ac.me

Sreten Savićević, Assoc. prof., Ing., Ph.D.

University of Montenegro, Faculty of Mechanical Engineering Džordža Vašingtona bb, 81000 Podgorica, Montenegro

E-mail: sreten.savicevic@ac.me 